удК 340.12

DOI

\author{
O.C. Заяив \\ orcid.org/0000-0003-2872-5567 \\ кандидат юридичних наук, \\ доцент кафедри иивільно-правових дисииплін \\ Львівського державного університету внутрішніх справ
}

\title{
ОБГРРУНУВАННЯ ОСНОВОПОЛОЖНИХ ПРИНЦИПІВ АДВОКАТА - СПРАВЕДЛИВОСТІ ТА ВІДПОВІДАЛЬНОСТІ
}

Відстоюючи ідею справедливості під час здійснення правосуддя, українські адвокати мають насамперед виходити з усвідомлення та розуміння факту, що незаконне рішення суду в принципі не можна визнавати. Судове рішення лише тоді набуває справедливого статусу, коли воно приймається на основі чинного законодавства й грунтується на засадах верховенства права. Підміна законів почуттями, емоціями, доцільністю - це шлях до руйнування правових основ будь-якого суспільства й держави. На жаль, окремі адвокати, поступаючись у професіоналізмі корифеям правозахисту, «чіплялися» за справедливість і намагалися компенсувати свої "скромні» можливості, втілюючи свою позицію в бездоганному силогізмі: для прикладу, в підсудного шестеро малолітніх дітей, якщо ми засудимо батька, його дітям доведеться помирати 3 голоду; але діти повинні жити, отже, ми не можемо засудити винного. Така позиція не має нічого спільного зі справедливістю. «Грамотний і чесний адвокат повинен знати, що кримінальна відповідальність не залежить від сімейного стану винного, і людина, яка вчинила злочин, має бути покарана, незважаючи на те, що його дружина й діти можуть померти з голоду; про них повинні подбати інші, насамперед держава й органи опіки, а судді й присяжні повинні зробити свою справу - прийняти справедливе правове рішення» [1, с. 239]. Безперечне й те, що імплементація таких емоцій є негідним прийомом захисту. Адвокат, який поважає правосуддя, знайде інші засоби й способи захисту - законні, морально виправдані й не менш ефективні.

Своєрідність соціального статусу, правової свідомості й специфіки виконуваної діяльності впливають на формування в адвоката специфічного відчуття справедливості, яке апріорі еквівалентно відбивається на його професійних особливостях. 3-поміж професійних особливостей адвоката, що потребують окремого дослідження, необхідно виділити, зокрема, такі:

1) стратифікація адвокатів на основі шкали корпоративного престижу;

2) самооцінка й оцінка 3 боку громадян (статусу, функцій);
3) відносини між різними прошарками фахівців, у тому числі й внутрішньо професійні конфлікти;

4) ступінь готовності юридичної спільноти до справжнього захисту прав і свобод людини;

5) специфіка професійного менталітету;

6) ступінь і варіанти опору з боку окремих адвокатів щодо нових правових інститутів (для прикладу, суд присяжних, допуск як захисників фахівців в галузі права й інше).

Хоча це навіть не весь перелік особливостей адвоката. Вони більшою мірою характеризують внутрішні відносини групи, з одного боку, і відбиваються на праворегулювальній функції (пошуку й встановленні справедливості), що ними виконується, - з іншого боку. Зрештою, як слушно висловився Джеймс Малхолланд, недофінансування значно карає жертв, аніж самих злочинців. Зокрема, Голова Асоціації кримінальних адвокатів зазначає: «Фінансування має вирішальне значення. Ми на колінах. Недофінансування ризикує поглибити судові помилки. Нам потрібно фінансувати обвинувачення, а також захист. Кожному потрібно платити гідно» [2].

Наведемо основні детермінанти професійної діяльності адвоката, які для зручності структурно розділимо на вісім складових компонентів: соціальний, пошуковий, реконструктивний (конструкційний), засвідчувальний, організаційний, конструктивний, пізнавальний, комунікативний.

Соціальний компонент діяльності адвоката визначається гуманним спрямуванням його професії, покладеним на нього суспільством, здійснювати правовий захист підозрюваного (обвинуваченого, підсудного) з метою досягнення справедливого розв'язання конфлікту між особистістю та суспільством, керуючись за такої умови принципом презумпції невинності. Утім, соціальний компонент діяльності адвоката вимагає від нього таких якостей:

1) гуманізм - вміння підтримати в клієнта зв'язок із суспільством, незважаючи на вчинений ним злочин;

2) віра в людину, що виражається в прогнозуванні соціально-корисної поведінки правопорушника; 
3) справедливість;

4) законність;

5) високий рівень кваліфікації.

Пошуковий компонент діяльності адвоката виражається:

1) у перевірці фактів, які надають слідчі й прокурор під час судового засідання, встановленні ï достовірності (істинності) або не достовірності (хибності);

2) в оцінці доказів в обгрунтуванні доведеності чи недоведеності фактів (оцінка думки фахівців, експертів);

3) у пошуку відповідних правових норм i, знову ж таки, оцінці можливості їх застосування.

Зрештою, пошуковий компонент діяльності адвоката передбачає наявність таких якостей: глибину мислення (здатність проникати в суть фактів) і широту розуму (вміння охоплювати широке коло питань); сумлінність; знання законодавства; визнання верховенства права; принциповість; наявність власної думки й вміння її відстоювати; особисту незацікавленість.

Реконструктивний (конструктивний) компонент діяльності адвоката як захисника в суді можна відбити в трьох стадіях:

1) складання загальної концепції - узагальнення різнобічної інформації, формування усталеної особистої думки, утвердження стратегії захисту;

2) розробка тактики захисту - підготовка тактичних прийомів, що дають можливість знайти з великого числа доказів лише ті, які б виправдовували його підзахисного чи пом'якшували його вину, в тому числі складання заяв і подань тощо;

3) проведення самого захисту.

Для реконструктивного (конструктивного) компоненту діяльності адвоката необхідна наявність і таких якостей, як-от: незалежність; розвинена пам'ять; критичне мислення; розвинена уява; уважність до деталей; коректність щодо колег в суді й інше.

Засвідчувальний компонент діяльності адвоката полягає у своєчасному й чіткому оформленні документації під час проведення консультацій і виступах як захисника в суді (заяви, скарги, інші документи правового характеру). Для цього адвокат повинен дотримуватися таких норм культури, як-от: акуратність; знання державної мови й мови регіону, де здійснюється адвокатська діяльність; вміння володіти лаконічним стилем викладу; вміння ефектно використовувати стандарти документації тощо.

Конструктивний компонент діяльності адвоката містить прийняття рішення про обрання тієї чи іншої стратегї та тактики захисту з урахуванням обставин справи й поведінки обвинуваченого. Вибір тактики захисту визначається її стратегією, яка може бути:

а) аналітичною (пошук доказів для виправдання підзахисного або пом'якшення його провини); б) побудованою на системі психологічних пасток для слідчого.

Крім того, до конструктивного компонента належать розумові операції щодо співвідношення ситуації злочину до змісту кримінальних і кримінально-процесуальних норм. Цей компонент діяльності адвоката також проявляється і під час визначення структури промови захисту в суді.

Організаційний компонент діяльності адвоката характеризується тим, що процес захисту не має суворої нормативної регуляції, тому планування захисту, використання певних прийомів i методів залежать від організаторських умінь адвоката.

Пізнавальний компонент діяльності адвоката спрямований на розв'язання складного завдання - встановлення істини з метою виправдання особи, яка притягається до відповідальності, або ж пом'якшення міри покарання. В основі пізнавального компонента лежить сувора й об'єктивна оцінка наявних фактів.

Комунікативний компонент діяльності адвоката дозволяє глибше вивчити психологічні причини скоєння злочину, дати повнішу характеристику особистості обвинуваченого, правильно будувати взаємини з іншими учасниками судового процесу, уникнути деструктивних ситуацій тощо.

Невіддільною частиною образу адвоката є його манера поведінки, тобто дії та вчинки, що демонструються як перед клієнтом, так і перед іншими представниками суспільства. Його поведінка зумовлена власними індивідуально-особистісними особливостями й відповідає тому образу, який він «прийняв» на себе. 3 огляду на це виникненню сумісності у відносинах між адвокатом і підзахисним сприяють професійні й особистісні якості захисника.

Для прикладу, Джеймі Спенхейк визначила п'ять рис великих юристів, зокрема такі:

1) співчуття як одна $з$ багатьох якостей юриста, оскільки без співчуття не можливо поставити себе на місце клієнта або повністю зрозуміти проблеми, з якими зустрічається клієнт. Окрім того, без співчуття не можливо зрозуміти позицію та свого суперника, передбачити, що він буде робити, і вжити необхідних превентивних кроків, щоб принести користь клієнту. Урешті-решт без цього не можливо запропонувати найкращі рішення;

2) уління слухати як один із найважливіших аспектів спілкування, адже це здатність слухати своїх клієнтів, суперників, своїх колег і суддів. Юристи повинні брати багато інформації, аналізувати й узагальнювати їі, а також добре розмірковувати, щоб надавати поради своїм клієнтам, а розпочинається все це саме з уміння слухати;

3) асертивність, а не агресивність, оскільки саме напористий адвокат висловлює свою думку 
й дає можливість себе почути, поважаючи й інших, натомість агресивні юристи нападають або ігнорують думки інших на користь своїх, що неприпустимо. Як і ті, кому бракує співчуття, надмірно агресивні адвокати не можуть зрозуміти чужу позицію, коли вона відрізняється від позиції їх клієнта. Це робить їх неефективними в розумінні проблеми й, отже, вони не в змозі надати ефективне рішення;

4) творчість як засіб пошуку реальних розв'язань проблем, на які наштовхуються клієнти, адже кожна справа є сама собою унікальною; 3 кожним клієнтом потрібно розв' язувати по-різному, а кожне рішення ретельно розробляти. Хоча загалом адвокат належить до досить несхильної спільноти, все ж він змушений навчитися мислити нестандартно;

5) наполегливість як запорука успіху.

Усе-таки адвокат повинен мати можливість піти геть, коли щось не працює, зробити перерву й повернутися свіжим і готовим до «боротьби», переговорів чи чого завгодно іншого [3].

Адвокат під час виконання правозахисних функцій повинен використовувати цивільний імунітет від безпідставних переслідувань органів влади за будь-які дії, що знаходяться в законодавчому полі, але суперечать позиції влади, оскільки були зумовлені його правовою позицією. Утім, адвокат повинен мати ось такий імунітет щодо всіх заяв, зроблених як усною, так і письмовою формою, щодо виконання ним професійних обов'язків у суді або іншому державному юридичному або адміністративному органі.

Слід зауважити, що саме суд займає центральне місце в системі правозахисних механізмів. Разом із тим світовий досвід підтверджує, що розвиток не судових правозахисних інститутів значно підвищує гарантії ефективності захисту прав людини. Зв'язок між гармонізацією суспільства (пошуком суспільного компромісу, суспільної справедливості), яку здійснює суд, і законодавчою гармонізацією існує на двох рівнях: строго правовому й здебільшого політичному. Саме останній має історичне значення, хоча й перший із них нині може бути важливішим.

Дослідження справедливості, законності й рівності як феноменів суспільного життя, зв'язку їх теоретичних положень з умовами імплементації містять не лише важливу наукову, а й практичну проблему. Під основними правами й свободами людини й громадянина зазвичай розуміють найбільш значущі 3 них, що закріплені в конституціях та інших нормативно-правових актах. Поняття «права» й «свободи» практично не відрізняються один від одного. Під правом у такому випадку розуміють суб'єктивне право діяти або не діяти в будь-який спосіб, а свобода - це відсутність перешкод для здійснення суб'єктивного права. Шлях права може бути звивистим, тому i є всі підстави вважати, що кінцева мета реалізації «права» й «свободи» полягає в тому, щоб всі громадяни мали реальну можливість реалізовувати свої справжні права, а суд, застосовуючи юридичну винахідливість, не перестарався в політичній доцільності. Взаємодія на основі права буде доречною лише в тому випадку, якщо суд ухвалює рішення, яке проголошує національну міру перешкоди будь-якому протизаконному посяганню. Якщо ухвалюють рішення про те, що такий захід можна зберегти внаслідок його виправданості, то це може стати судовою практикою, на яку, як на «британський судовий прецедент по-українськи», в разі проблемних процесів з особливо помітною політичною складовою частиною зможуть спиратися наступні суди тощо.

Важливо, щоб саме громадяни, а не професійні політики, не ізолювали себе від політичного життя суспільства й прагнули брати в ньому активну участь із метою унеможливлення негативного впливу плюралізму думок на державну політику. Сучасність неодноразово доводила, що адвокат як юрист, що володіє індивідуальною політичною культурою, відіграє значну роль у формуванні демократичної особистості, розвитку громадянського суспільства й правової держави. Тому й політична культура адвоката - це зумовлені політичними знаннями, вміннями, навичками, цінностями й втілені на практиці правила (норми) його поведінки як суб'єкта політичної влади. Отже, саме рівень політичної культури адвоката формує розуміння ним власного впливу на формування та утвердження в суспільстві такої цінності, як справедливість.

Справедливість як стрижень адвокатської діяльності загалом пов'язана з ще одним аксіологічним принципом діяльності адвоката, а саме 3 відповідальністю. Власне, відповідальність адвоката є відповідністю поведінки адвоката до соціально-нормативних вимог, його професійного обов'язку, підпорядкованістю його поведінки соціальному контролю. Зрештою, як слушно із цього приводу відзначає В.С. Бліхар: «Коли людина вчиняє правильно відповідно до системи цінностей і норм закону, то із часом у неї виробляється звичка вчиняти морально й правослухняно. У такий спосіб людина формує свої моральноправові якості - стійкі риси характеру, що виражені в її поведінці, вчинках у конкретних ситуаціях" [4, с. 133]. На думку саме цього автора, цінність правової допомоги безпосередньо залежить від особи, яка її надає, - юриста. «Цю людину, - акцентує В'ячеслав Бліхар, - можна схарактеризувати сукупністю таких рис: синкретизм моралі й права; вищий за загальностатистичний культурний рівень правосвідомості, що зумовлено вимогами до юридичного фаху; усвідомлене прийняття 
у свою поведінку й загальнолюдських, і спеціальних правил, розроблених відповідно до вимог юридичного фаху; пріоритет таких рис характеру, як стриманість, порядність, ввічливість, відповідальність тощо» [4, с. 134].

Для прикладу, Джон Ф. Шерман визначив шість причин, чому юристи повинні займатися адвокатською діяльністю з дотриманням прав людини. Зокрема, він виокремив:

1) управління ризикали, оскільки нездатність компанії керувати своїми ризиками в галузі прав людини може мати серйозні ризики для самої компанії, включаючи юридичні ризики;

2) cmiǔкість як гарантія визнання міжнародними компаніями управління ризиками, пов'язаними з правами людини як важливим компонентом для своїх цілей у сфері стійкості. Вони очікують, що їхні найцінніші адвокати - як всередині, так і зовнішні адвокати - будуть консультувати їх із питань прав людини як частину їх ширшого управління юридичними ризиками;

3) мінливість закону, оскільки закон динамічний, а не статичний. Закони, які вимагають від компаній дотримуватись прав людини, стають все глобальнішими, що останнім часом спостерігається в законодавстві, котре вимагає звітування про ризики прав людини тощо;

4) відповідність і національне законодавство. Адвокати можуть зіграти вирішальну роль, допомагаючи компаніям виконувати національне законодавство, яке захищає права людини. Адвокати також можуть надати ключові поради, щоб допомогти клієнтам зрозуміти й подолати потенційну напруженість між національним законодавством і правами людини;

5) запобігання заподіяння шкоди правал люди $н u$, адже є чимало галузей юридичної практики, де адвокати можуть допомагати компанії запобігти або ж пом'якшити проблеми з правами людини, наприклад, формуючи, як компанія обирає, укладає контракти, контролює результати діяльності й припиняє чи поновлює відносини 3 третіми сторонами, які можуть потенційно призводити компанію до проблем із правами людини;

6) професійна етика юриста, адже адвокати повинні діяти в інтересах своїх клієнтів і визнають, що їхня роль у дотриманні верховенства права є фундаментальною для відповідальності суспільства й держави за дотримання прав людини. Мало того, в багатьох правових кодексах чітко згадуються права людини як складова частина саме етичного законодавства [5].

У такому контексті необхідно акцентувати на тому, що все ж таки професійна етика загалом є стрижнем у забезпеченні незалежної, компетентної, ефективної та підзвітної адвокатської діяльності. Утім, вичерпні етичні правила або професійна поведінка повинні гарантувати, що адвокати дотримуватимуться процедур догляду за клієнтами, діятимуть в інтересах клієнта й виконуватимуть свої обов'язки адвоката. Отже, доцільно й констатувати, що саме професійна етика може додатково прищепити аксіологічні принципи справедливості, чесності й доброчесності в поведінці юристів і зміцнити довіру громадськості до здійснення правосуддя. Адже адвокати на міжнародній арені є спеціалізованими фахівцями, які ставлять інтереси своїх клієнтів вище особистих i прагнуть домогтися верховенства права. Саме адвокат зобов'язаний поєднувати у своїй практичній діяльності постійне оновлення правових подій з обслуговуванням своїх клієнтів, повагою до судів і законним прагненням підтримувати правослухняний рівень життя.

Відповідно до такого підходу відповідальність адвоката є різновидом громадсько-правової відповідальності. Отже, до ознак, притаманних відповідальності адвоката, як вдало їх виокремила О.А. Фаєр, можна віднести всі ознаки, характерні для громадсько-правової відповідальності, а саме: державний примус, засудження суспільства, негативні наслідки для правопорушника, майновий характер, додаткові обмеження, відповідальність юридично-рівних суб'єктів один перед одним, компенсаторний характер [6, с. 628]. Окрім того, професійна відповідальність адвоката має певні ознаки, що дозволяють її виокремлення як окремого виду юридичної відповідальності. Наявність самостійних джерел, що містять у собі норми, які регулюють функціонування професійної відповідальності адвоката, є ще однією ознакою професійної відповідальності адвоката. До таких джерел відносять: Кодекс професійної етики адвоката, корпоративні акти адвокатських палат, прецеденти адвокатських палат, звичаї тощо.

Наявність процесуального права, що регулює порядок, скажімо, притягнення адвоката до професійної відповідальності, $€$ незаперечною ознакою наявності окремого виду юридичної відповідальності - професійної відповідальності адвоката. Таким чином, у випадку притягнення адвоката до професійної відповідальності до компетенції одного органу входить встановлення факту наявності в діяльності адвоката порушення норм адвокатської етики (кваліфікаційна комісія), а до компетенції другого - вибір міри професійної відповідальності (рада адвокатської палати). Справедливості ради необхідно відзначити, що виокремлення нового виду юридичної відповідальності - професійної відповідальності, як і його підвиду - професійної відповідальності адвоката, може послужити імпульсом для доктринального вивчення великого пласта соціальних відносин, пов'язаних із діяльністю саморегульованих професійних відносин. Отже, говорити про відповідальність адвоката як один із видів 
дисциплінарної відповідальності в її класичному розумінні, на мій погляд, буде не правильним. Усе ж дотримуюся переконання, що відповідальність адвоката є самостійним видом юридичної відповідальності.

Урешті-решт, певна складність становища адвоката полягає в односторонності функції захисника. Адвокат на відміну від прокурора з'ясовує виключно ті обставини у справі, що виправдовують або ж пом'якшують вину чи ступінь відповідальності підзахисного. Одна з перших заповідей Гіппократа лікарям «Не нашкодь» цілком логічно імплементована й у діяльність адвоката: своєю діяльністю він зобов'язаний не зашкодити позиціям та інтересам свого клієнта. У такому проявляється одна з найхарактерніших специфічних моральних вимог до адвоката.

Підсумовуючи, потрібно акцентувати на тому, що, зважаючи на специфіку інституту професійної відповідальності адвоката, слід задуматися над його подальшим розвитком, перспективою та проблемами. У чинних правилах адвокатської етики норми викладені досить не чітко й не системно. Проте для початку процесу внесення змін у цей документ слід все-таки з'ясувати, чи влаштовує сучасну адвокатську спільноту ситуація, що склалася з притягненням адвокатів до професійної відповідальності? Вочевидь, ні.

Аналіз правозастосовної практики 3 приводу притягнення адвокатів до професійної відповідальності відбив, що низка важливих правил не знайшла свого закріплення в Правилах адвокатської етики. Лише після вдосконалення інституту професійної відповідальності адвоката можемо переходити до кардинально нового етапу розвитку цього інституту - формування складу професійних правопорушень адвокатів, оскільки безліч наявних проблем в адвокатській діяльності пов'язані передусім із тим, що адвокат виконує своєрідну суспільну роль, гармонізуючи й гуманізуючи суспільні відносини, а водночас не є державним інститутом.

\section{Jimepamypa}

1. Ильин И.А. Путь к очевидности. Москва : Республика, 1993. 441 с.

2. Mulholland J. Criminal justice system is "on its knees", says top English lawyer. URL: https://www.theguardian.com/law/2020/nov/19/ criminal-justice-system-is-on-its-knees-says-top-englishlawyer.

3. Spannhake J. Five Traits of Great Lawyers. URL: https://www.attorneyatwork.com/five-traitsgreat-lawyers/.

4. Бліхар В.С. Екзистенція правової допомоги як філософсько-правового феномену. Вic ник Національного університету «Львівська по літехніка». Серія: Юридичні науки. 2016. № 855. C. $130-135$.

5. Sherman J.F. Six Reasons Why Lawyers Should Practice Law with Respect for Human Rights (The International Bar Association has issued draft guidance for legal professionals on the Guiding Principles). URL: https://shiftproject.org/six-reasons-why-lawyersshould-practice-law-with-respect-for-human-rights/.

6. Файєр О.А. Поняття професійної відповідальності та підстави іï виникнення. Форум права. 2009. № 3. C. 627-633. URL: http://nbuv.gov.ua/UJRN/FP index.htm_2009_3_98.

\section{Анотація}

Заяиь О. С. Обгрунтування основоположних принципів адвоката - справедливості та відповідальності. - Стаття.

Стаття присвячена обгрунтуванню основоположних в адвокатській діяльності принципів справедливості й відповідальності в межах філософсько-правового дискурсу. 3'ясовано, що 3-поміж похідних від аксіологічних принципів правозахисної діяльності адвоката необхідно виокремити передусім ідею справедливості в здійсненні правосуддя. Отже, доведено, що, як і гуманізм, справедливість є морально-юридичною категорією. Утім, констатується, що, хоча ідея справедливості й пронизує весь кримінальний процес, впливаючи на якісний характер не лише прийнятих рішень, а й вибору способів їх досягнення, все ж натепер вона залишається більшою мірою декларативним принципом. Відзначено, що своєрідність соціального статусу, правової свідомості й специфіки виконуваної діяльності безпосередньо впливають на формування в адвоката особливого відчуття справедливості, що апріорі еквівалентно впливає на його професійні особливості. Тому з огляду на це однією з умов успішної діяльності адвоката, як у професійно-правозахисному, так і в представницькому напрямах є набуття ним високої політичної культури. Отже, саме рівень політичної культури адвоката впливає на розуміння ним особистої відповідальності за формування та утвердження в суспільстві такого принципу, як справедливість. Цей принцип безпосередньо пов'язаний із ще одним аксіологічним принципом діяльності адвоката, а саме 3 відповідальністю як відповідністю поведінки адвоката соціально-нормативним вимогам, його професійному обов'язку, підпорядкованістю його поведінки соціальному контролю та інше. Таким чином, в тексті статті зображено, що відповідальність адвоката є різновидом суспільно-правової відповідальності. Отже, стверджується, що, зважаючи на специфіку інституту професійної відповідальності адвоката, слід задуматися про його подальший розвиток, перспективи й проблеми, які в чинних правилах адвокатської етики викладені не достатньою мірою та не системно. Запропоновано для початку процесу внесення змін у цей кодекс все ж таки з'ясувати, чи влаштовує сучасну адвокатську спільноту ситуація, що виникла навколо притягнення адвокатів до професійної відповідальності? Вочевидь ні. Що й зумовлює актуальність проведеного дослідження.

Ключові слова: держава, суспільство, особистість, адвокат, адвокатська діяльність, справедливість, відповідальність.

\section{Summary}

Zaiats $0 . \quad S$. Substantiation of the fundamental principles of the lawyer - fairness and responsibility. - Article.

The article is devoted to substantiation of the fundamental principles of justice and responsibility within the framework of philosophical and legal discourse. It 
was found that among the derivatives of the axiological principles of human rights advocacy, it is necessary to single out the idea of justice in the administration of justice. Thus, it is proved that, like humanism, justice is a moral and legal category. However, it is stated that although the idea of justice permeates the entire criminal process, influencing the qualitative nature not only of the decisions made, but also the choice of ways to achieve them, still today it remains, to a greater extent, a declarative principle. It is noted that the uniqueness of social status, legal consciousness and the specifics of the activities directly affect the formation of a lawyer's specific sense of justice, which, a priori, has an equivalent effect on his professional characteristics. Therefore, in view of this, one of the conditions for the successful activity of a lawyer, both in professional and human rights, and in the representative areas is the acquisition of a high political culture. Thus, it is the level of political culture of the lawyer that influences his understanding of personal responsibility for the formation and establishment in society of such a principle as justice. This principle is directly related to another axiological principle of the lawyer's activity, namely responsibility, as compliance of the lawyer's behavior with social and normative requirements, his professional duty, subordination of his behavior to social control, etc. Thus, it is reflected in the text of the article that the responsibility of a lawyer is a kind of social and legal responsibility. Therefore, it is argued that given the specifics of the institution of professional responsibility of a lawyer should think about its further development, prospects and problems, which in the current rules of legal ethics are not set out sufficiently and not systematically. It is suggested that in order to start the process of amending this code, it is still necessary to find out whether the current legal community is satisfied with the situation that has arisen around bringing lawyers to professional responsibility? Obviously not. Which determines the relevance of the study.

Key words: state, society, personality, lawyer, advocacy, justice, responsibility. 